\title{
Critical loads of nitrogen deposition and critical levels of atmospheric ammonia for semi-natural Mediterranean evergreen woodlands
}

\author{
P. Pinho ${ }^{1,2}$, M. R. Theobald ${ }^{3,4}$, T. Dias ${ }^{1}$, Y. S. Tang ${ }^{4}$, C. Cruz ${ }^{1}$, M. A. Martins-Loução ${ }^{1,5}$, C. Máguas ${ }^{1}$, M. Sutton ${ }^{4}$, and \\ C. Branquinho 1 \\ ${ }^{1}$ Universidade de Lisboa, Faculdade de Ciências, Centre for Environmental Biology, Lisboa, Portugal \\ ${ }^{2}$ Centre for Natural Resources and the Environment, Instituto Superior Técnico, Universidade Técnica de Lisboa, Portugal \\ ${ }^{3}$ Dept. Agricultural Chemistry and Analysis, E.T.S.I. Agrónomos, Technical University of Madrid, Spain \\ ${ }^{4}$ Centre for Ecology and Hydrology, Edinburgh Research Station, Edinburgh, UK \\ ${ }^{5}$ Universidade de Lisboa, Museu Nacional de História Natural, Jardim Botânico, Lisboa, Portugal
}

Correspondence to: C. Branquinho (cmbranquinho@fc.ul.pt)

Received: 11 September 2011 - Published in Biogeosciences Discuss.: 21 November 2011

Revised: 6 March 2012 - Accepted: 7 March 2012 - Published: 28 March 2012

\begin{abstract}
Nitrogen (N) has emerged in recent years as a key factor associated with global changes, with impacts on biodiversity, ecosystems functioning and human health. In order to ameliorate the effects of excessive $\mathrm{N}$, safety thresholds such as critical loads (deposition fluxes) and levels (concentrations) can be established. Few studies have assessed these thresholds for semi-natural Mediterranean ecosystems. Our objective was therefore to determine the critical loads of $\mathrm{N}$ deposition and long-term critical levels of atmospheric ammonia for semi-natural Mediterranean evergreen woodlands. We have considered changes in epiphytic lichen communities, one of the most sensitive comunity indicators of excessive $\mathrm{N}$ in the atmosphere. Based on a classification of lichen species according to their tolerance to $\mathrm{N}$ we grouped species into response functional groups, which we used as a tool to determine the critical loads and levels. This was done for a Mediterranean climate in evergreen cork-oak woodlands, based on the relation between lichen functional diversity and modelled $\mathrm{N}$ deposition for critical loads and measured annual atmospheric ammonia concentrations for critical levels, evaluated downwind from a reduced $\mathrm{N}$ source (a cattle barn). Modelling the highly significant relationship between lichen functional groups and annual atmospheric ammonia concentration showed the critical level to be below $1.9 \mu \mathrm{g} \mathrm{m}^{-3}$, in agreement with recent studies for other ecosystems. Modelling the highly significant relationship between lichen functional groups and $\mathrm{N}$ deposition showed that the critical load was lower than $26 \mathrm{~kg}(\mathrm{~N}) \mathrm{ha}^{-1} \mathrm{yr}^{-1}$, which is within the
\end{abstract}

upper range established for other semi-natural ecosystems. Taking into account the high sensitivity of lichen communities to excessive $\mathrm{N}$, these values should aid development of policies to protect Mediterranean woodlands from the initial effects of excessive $\mathrm{N}$.

\section{Introduction}

Fixation of atmospheric $\mathrm{N}_{2}$ to reactive nitrogen $\left(\mathrm{N}_{\text {reac }}\right)$ allowed its use as fertilizer for agriculture, supporting an unprecedented increase in human population (Erisman et al., 2008). This agriculture-related $\mathrm{N}_{\text {reac }}$ (mostly supplied as reduced nitrogen, $\mathrm{NH}_{3} / \mathrm{NH}_{4}^{+}, \mathrm{N}_{\text {red }}$ ), together with that emitted from fossil fuel combustion (mostly oxidized nitrogen, $\mathrm{NO}_{\mathrm{x}}$ ) was in 2007 at least equal to the amount of nitrogen (N) fixed by non-human processes (UNEP and WHRC, 2007). A large fraction of $\mathrm{N}_{\text {reac }}$ escapes into ecosystems, and as a consequence, the presence of excess $\mathrm{N}$ is increasingly detected across ecosystems (Erisman et al., 2008), causing alterations to plant biodiversity (Bobbink et al., 2010), ecosystem functioning (Manning et al., 2006) and also affects human health (Galloway et al., 2003). In fact, together with the rates of climate changes and biodiversity loss, the rate of human interference on the $\mathrm{N}$ cycle was considered to have passed the safety boundary for human wellbeing on Earth (Rockstrom et al., 2009). 
In order to protect ecosystem functioning from excessive $\mathrm{N}_{\text {reac }}$, the concepts of critical loads (CLOs) of nitrogen deposition $\left(\mathrm{N}_{\mathrm{dep}}\right)$ and, more recently, of critical levels (CLEs) of atmospheric ammonia, have been defined. In this work the CLOs are a quantitative estimate of exposure to $\mathrm{N}_{\mathrm{dep}}$ below which significant harmful effects on specified sensitive elements of the environment at the ecosystem level do not occur according to present knowledge (Nilsson and Grennfelt, 1988). The CLEs correspond to the concentration of atmospheric ammonia $\left(\left[\mathrm{NH}_{3}\right]_{\mathrm{atm}}\right)$ above which direct adverse effects may occur according to present knowledge (Cape et al., 2009). It is important to note that while the CLO corresponds to the total amount of $\mathrm{N}$ deposited from the air, the CLE refers only to the concentration of ammonia in the atmosphere. The CLOs for $\mathrm{N}$ deposition have been recently revised, with values ranging from 3$30 \mathrm{~kg} \mathrm{ha}^{-1} \mathrm{yr}^{-1}$ for Europe (Bobbink et al., 2011) and between $1-25 \mathrm{~kg} \mathrm{ha}^{-1} \mathrm{yr}^{-1}$ for North America (Pardo et al., 2012). The same occurred for long-term (annual) CLEs, for which a reduction from $8 \mu \mathrm{g} \mathrm{m}^{-3}$ to $1 \mu \mathrm{g} \mathrm{m}^{-3}$ was recommended to the United Nations Economic Commission for Europe, UNECE (Hallsworth et al., 2010; Pinho et al., 2009).

Although CLOs and CLEs are important in environmental policies (Fenn et al., 2010), most of the values are based on work done on temperate ecosystems (Fenn et al., 2007; Rogers et al., 2009; Wolseley et al., 2006; Geiser et al., 2010), but not on Mediterranean ones (Bobbink et al., 2011), with the exception of Mediterranean California (Fenn et al., 2010; Ochoa-Hueso et al., 2011). This currently prevents the establishment of empirical CLOs and CLEs for Mediterranean systems outside California. However, California is rather different from the European-Mediterranean areas, on what regards the historical land-use and current spatial distribution of artificial vs. natural areas, which are spatially apart from each other. In fact, unlike other regions of the world, in the European-Mediterranean area- a biodiversity hotspot (Mittermeier et al., 2005; Myers et al., 2000), we can find a large variety of land-cover types in relatively small areas (Blondel and Aronson, 1999; Farina et al., 2005), where small areas with high conservation value mix with low-intensity agriculture and small urban settlements, forming a patchy landscape. These ecosystems, managed for millennia, are species rich and are nowadays the target of conservation policies (Plieninger et al., 2006) and can be classified as "High Nature Value Farmland" (Paracchini et al., 2008). Farmlands area which can be regarded as "High Nature Value Farmlands" reaches $52 \%$ in European-Mediterranean countries (32\% overall in Europe and $27 \%$ in non-Mediterranean countries) (Paracchini et al., 2008). Moreover, due to historical transformation of ecosystems by man, in most EuropeanMediterranean countries we can no longer find extensive pristine forests. Because Mediterranean evergreen woodlands are semi-natural ecosystems with high biodiversity and simultaneously provide a large number of other services that depend on low-intensity human management (Bugalho et al.,
2011) it is important to know the thresholds for these seminatural areas, in order to protect them from the effects of management intensification. Only recently, the first values for empirical CLOs for Mediterranean maquis vegetation was published based on expert knowledge (Bobbink et al., 2011; Dias et al., 2011). Other studies on the effect of excessive $\mathrm{N}_{\text {dep }}$ and $\left[\mathrm{NH}_{3}\right]_{\text {atm }}$ on European-Mediterranean ecosystems were not suitable for establishing CLOs and CLEs due to: (i) the short time periods of $\mathrm{N}$ addition to the ecosystem (less than $2 \mathrm{yr}$ ) (Bonanomi et al., 2006): (ii) the $\left[\mathrm{NH}_{3}\right]_{\mathrm{atm}}$ measurements being less than 3 months (Frati et al., 2007; Pinho et al., 2009); and iii) the lack of response of the tested parameters, e.g. N leakage (Roda et al., 2002). In order to avoid these limitations we have worked on an site with a continuous source of $\mathrm{N}_{\text {red }}$ (a cow barn operated in similar conditions for more than $20 \mathrm{yr}$ ), located in an region with a constant background $\mathrm{N}_{\mathrm{dep}}$ for at least $20 \mathrm{yr}$ (Simpson et al., 2003), and measured $\left[\mathrm{NH}_{3}\right]_{\mathrm{atm}}$ for an entire year, thus observed changes should reflect the integrated effect of Nred pollution at the ecosystem level. Although $\mathrm{N}$ addition studies are the only way to ensure that the observed effects are due to $\mathrm{N}$, these studies are not frequently done with enough time and realistic $\mathrm{N}$ doses (Bonanomi et al., 2006; Dias et al., 2011). N-addition studies can be complemented with gradient studies, where we can ensure a long-term $\mathrm{N}$-supply and realistic $\mathrm{N}$ doses (Bobbink et al., 2011). We have focused on the effect of $\mathrm{N}_{\text {red }}$ because, unlike $\mathrm{NO}_{\mathrm{x}}$, the emissions of this $\mathrm{N}$ form haven remained constant on the last years and are not expected to decrease significantly in the future, at least in Europe and United States (Reis et al., 2009).

The establishment of CLOs for $\mathrm{N}_{\text {dep }}$ has used several strategies, being most commonly based on empirical work, although a modelling approach has also been used (Fenn et al., 2008). The establishment of CLEs for ammonia has been mostly grounded on empirical work (Bobbink et al., 2011; Fenn et al., 2008), quantifying the effect of increasing $\left[\mathrm{NH}_{3}\right]_{\text {atm }}$ on a receptor (Cape et al., 2009). In fact, due to lichens dependence on atmospheric nutrition, lichens respond directly to atmospheric pollution, making them ideal to establish thresholds of airborne N. Lichens have frequently been used to assess the effects of industrial pollution ( $\mathrm{Au}-$ gusto et al., 2009; Branquinho et al., 2008; Giordani, 2007; Pinho et al., 2004) providing spatially explicit information on the effects of those pollutants (Pinho et al., 2008a, b). For both CLOs and CLEs, lichen communities have been used as one of the most sensitive receptors; recent proposal for revision of CLEs was mainly based on alterations in lichen communities (Cape et al., 2009; Fenn et al., 2008) and the most recent CLOs established for a large number of ecosystems were also based on lichens (Bobbink et al., 2011). Specifically regarding the effects of $\mathrm{N}_{\text {red }}$, a successful strategy was the use of lichen functional response groups (Lavorel and Garnier, 2002), i.e. groups of species with a similar response to an environmental factor. It is known that under increasing $\mathrm{N}$ availability, nitrophytic species are favoured 
and oligotrophic species decline (Pinho et al., 2008b, 2009, 2011; Sparrius, 2007). An additional advantage of using lichens is that, due to the high sensitivity of some species, they can be considered as early warning tools, i.e. a change in lichen communities can signal a change in ecosystems before a critical and possible irreversible transition occurs (Scheffer et al., 2009). Although bryophytes and lichens communities seem equally sensitive to excessive $\mathrm{N}_{\text {reac }}$, lichens are more abundant in the Mediterranean ecosystems and a standard lichen sampling method is available (Asta et al., 2002), allowing inter-comparisons across different regional areas. Nevertheless in order to have a wider perspective on $\mathrm{N}$ impacts on ecosystems it would be necessary to study other ecosystem components that are more dependent on the soil, such as plants, fungi and invertebrates (Feest and Spanos, 2009).

Our objective was to determine the critical loads (CLOs) for $\mathrm{N}$ deposition and the critical levels (CLEs) for atmospheric ammonia for Mediterranean evergreen woodlands. We hypothesize that the response of lichen functional groups at increasing distances from agriculture $\mathrm{N}_{\text {red }}$ source could be used to calculate both CLOs and CLEs using modelled $\mathrm{N}_{\text {dep }}$ and measured $\left[\mathrm{NH}_{3}\right]_{\text {atm }}$ in cork-oak (Quercus suber L.) woodland. The current work is an expansion and improvement of a previous work that approached the calculation of CLEs only and was based on three months measurement of $\left[\mathrm{NH}_{3}\right]_{\text {atm }}$ (Pinho et al., 2009). Here we calculate the CLOs and CLEs, utilizing one-year $\left[\mathrm{NH}_{3}\right]_{\mathrm{atm}}$ measurement data and make use of an improved functional groups classification and geostatistical interpolation (Pinho et al., 2011).

\section{Methods}

\subsection{Study site and sampling}

The study site was located $30 \mathrm{~km}$ East of Lisbon, Portugal, within a mixed agricultural landscape where a number of high-intensive agriculture hotspots (mostly high-intensity animal farming and irrigated crops) are mixed with lowintensive agriculture activities (mostly extensive pastured cork-oak woodlands). The study site was cork-oak woodland, Eunis class G2.1, "Mediterranean evergreen oak woodland" (Davies et al., 2004). This area is under a constant background $\mathrm{N}_{\mathrm{dep}}$ for at least $20 \mathrm{yr}$ (Simpson et al., 2003). At the upwind edge of this woodland, there is a high-intensity point-source of $\mathrm{N}_{\text {red }}$, a barn permanently housing ca. 200 beef-cattle. More details can be found elsewhere (Pinho et al., 2011). Within the woodland we characterized: (i) lichens species frequency; (ii) nitrogen deposition; and (iii) atmospheric ammonia concentrations (Fig. 1).

For lichen sampling, a total of 74 points (trees) were selected (Fig. 1) ensuring that the trees had no branches at sampling height, no signs of disease and that the deviation from vertical was less than $10^{\circ}$ (Pinho et al., 2004). Lichens

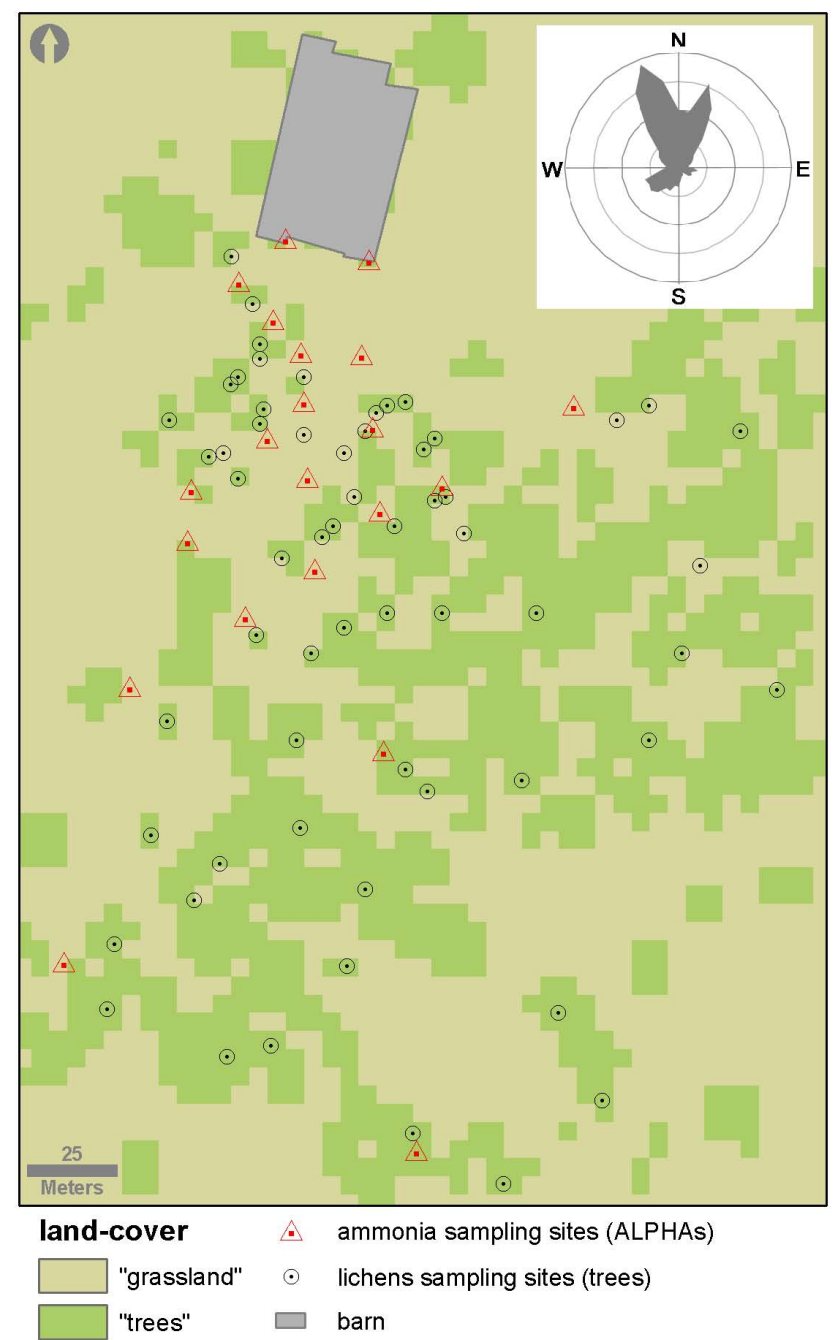

Fig. 1. Sampling design and wind direction. In cork-oak woodland we assessed lichen functional diversity, measured atmospheric ammonia concentration over one year period, and modelled $\mathrm{N}$ deposition using LADD model considering the land-cover ("trees" and "grass"), the wind direction and considering the barn as the source of $\mathrm{N}$. The wind direction is the $\%$ of wind occurrence from each direction in $10^{\circ}$ interval, during the sampling period. The full circle is $10 \%$.

were sampled in un-harvested cork accordingly to a standard protocol (Asta et al., 2002), using a $50 \times 10 \mathrm{~cm}$ grid, divided in five $10 \times 10$ squares placed on the four main aspects of the trunk (N, E, S and W) between one and two meters from the ground. All lichen species growing within the grid were identified and the number of squares in which each species was found was recorded as the species frequency. From these data we calculated a standard value, LDV (Lichen Diversity Value) that accounts for both species richness and their frequency (Asta et al., 2002). Because lichen functional groups based on tolerance to eutrophication were shown to respond more significantly to $\left[\mathrm{NH}_{3}\right]_{\text {atm }}$ than total diversity 
(Pinho et al., 2009, 2011), LDV was calculated by grouping species into two contrasting response functional groups (Lavorel and Garnier, 2002): nitrophytic or N-tolerant (LDVnitro) and oligotrophic or N-sensitive (LDVoligo) (Table 1). Species ranked as intermediate (mesotrophic) were not used because their relation to $\left[\mathrm{NH}_{3}\right]_{\text {atm }}$ was less significant (Pinho et al., 2011). Lichen species grouping was based on an international classification of Italian species to eutrophication tolerance (Nimis and Martellos, 2008) after correcting for some species classification (Pinho et al., 2011).

The $\mathrm{N}_{\text {dep }}$ was estimated for the entire study site area (Fig. 1) using Local Atmospheric Dispersion and Deposition (LADD) model (Theobald et al., 2004). The use of transport and deposition models such as LADD to understand the fate of ammonia emitted from point sources is important due to the short-range deposition of most N, allowing the establishment of local environmental policies (Dragosits et al., 2002). LADD model takes as inputs: the land-cover on a user-specified grid (Fig. 1), the ammonia source (the "barn" in Fig. 1), the animals emission rate and meteorological data. The land-cover map was performed by manual interpretation of aerial photography (2005) distinguishing three land-cover categories: "trees" (the tree canopy), "grass" (areas between the canopies) and "barn" (Fig. 1). No significant amount of other land-cover types, such as shrubs or other buildings, were present in the study site. Land-cover was then transformed from vector to raster format, using a $5 \mathrm{~m}$ resolution grid. Meteorological data, namely wind speed and direction, were collected from the nearest station, in military base (BA6, Força Aérea Portuguesa). In the absence of specific Portuguese emission factors, the animals' emissions were calculated using European emission factors (EEA, 2007) assumming an average barn ocuppation of 200 animals. Using the LADD model we then estimated dry $\mathrm{N}_{\text {dep }}$ within our study site area for the same period when the $\left[\mathrm{NH}_{3}\right]_{\mathrm{atm}}$ measurements were performed and added this value to the total background $\mathrm{N}$ deposition rate predicted by the EMEP Unified Model (Simpson et al., 2003).

The $\left[\mathrm{NH}_{3}\right]_{\text {atm }}$ was measured at 21 points (Fig. 1), during 11 periods from October 2006 to November 2007 (Pinho et al., 2011) using high-sensitivity ALPHA passive diffusion samplers (Tang et al., 2001). The ALPHA samplers contained a cellulose filter impregnated with citric-acid as adsorbent $(13 \% \mathrm{w} / \mathrm{v})$ and after being exposed in the field were extracted into deionised water and analysed for ammonium $\left(\mathrm{N}-\mathrm{NH}_{4}^{+}\right.$) by colorimetry on a Spectra Rainbow A-5082 spectrophotometer (Tecan, Männedorf, Switzerland), using a modified Berthelot reaction (Cruz and Martins-Loução, 2000). Measurement quality was assured with parallel analyses using an Ammonium Flow Injection Analysis system (Sutton et al., 2001). Further details can be found elsewhere (Pinho et al., 2011). The $\left[\mathrm{NH}_{3}\right]_{\text {atm }}$ values given are the mean of the 11 sampling periods, expressed in $\mu \mathrm{g} \mathrm{m}^{-3}$.

Since all the work was performed in a farm environment, even the more distant sampling points could be experiencing
$\mathrm{N}$ concentrations higher than the background. For this reason, we compared the LDVs of lichen functional groups measured in our study site to the ones measured in a control area. This control area, Campo de Tiro de Alcochete (Pinho et al., 2012 ) is located $8 \mathrm{~km}$ to the NW of our study site, within military grounds and without any known nearby sources of $\mathrm{N}_{\text {red }}$ and at the same distance from possible $\mathrm{NO}_{\mathrm{x}}$ sources (more than $20 \mathrm{~km}$ ). Taking this into account, $\mathrm{N}_{\mathrm{dep}}$ and $\left[\mathrm{NH}_{3}\right]_{\mathrm{atm}}$ were assumed to be lower at the control area than at the study site and we considered the LDVs from the control area to be our control LDVs. The control area is similar to the study site, with the same type of vegetation (cork-oak woodland), soil, climate and background $\mathrm{N}_{\mathrm{dep}}$ as estimated by the EMEP Unified Model output (Simpson et al., 2003). The same methodology was followed for sampling lichens and calculating the LDVs of functional groups. In this control area, 16 sampling plots located in areas without cattle were used and the mean values were considered as the control LDVs (Pinho et al., 2012). Taking into account that the control LDV plots are located in the same type of ecosystems, seminatural Mediterranean evergreen woodlands, the calculated critical loads of nitrogen deposition and critical levels of atmospheric ammonia refer to thresholds for this semi-natural ecosystem, not to thresholds for pristine ecosystem.

\subsection{Critical loads of nitrogen deposition and critical levels of atmospheric ammonia}

For calculating CLOs (Nilsson and Grennfelt, 1988) and CLEs (Cape et al., 2009) we modelled the linear relationship between both the LDVs with $\mathrm{N}_{\text {dep }}$ and $\left[\mathrm{NH}_{3}\right]_{\text {atm }}$ respectively. The control LDV was included in these models and the first observed sampling point that presented a LDV different from the control was considered already changed. According to its definition, the last unaltered point was used to calculate the CLOs and the first altered point for calculating the CLEs. Taking these points and considering the $95 \%$ confidence interval of the linear relationship (Cape et al., 2009), the CLOs and CLEs were determined. In all regressions the residuals approached a normal distribution and presented an acceptable level of homogeneity, especially when taking into account the large number of samples used in the CLO regressions.

For calculating CLOs, the LDVs and $\mathrm{N}_{\text {dep }}$ were correlated at the lichen sampling sites $(\mathrm{N}=54$, trees located outside the LADD model domain were not used, Fig. 1). Most lichen sampling sites were located in "tree" land-cover (Fig. 1). When that was not the case, which was due to the resolution of the land-cover model (because lichens were observed on trees), the $\mathrm{N}_{\mathrm{dep}}$ for the nearest "tree" land-cover pixel was used, which was always less than $3 \mathrm{~m}$ from the point. This was done because LADD predicts much larger deposition rates to "trees" than to "grasslands".

For correlating LDVs with $\left[\mathrm{NH}_{3}\right]_{\mathrm{atm}}$, an interpolation of one of those variables was necessary, because they were not 
Table 1. Lichens species classification into functional response groups regarding eutrophication tolerance, based on Nimis and Martellos, 2008. The maxima of the original "species indicator values" were taken and species with a maximum value of 1 or 2 were considered oligotrophic, species with a maximmum classification of 3 were considered mesotrophic, species with a maximum classificaiton of 4 or 5 were considered nitrophytic.

\begin{tabular}{cl}
\hline functional group & lichen species \\
\hline & Amandinea punctata (Hoffm.) Coppins \& Scheidegger, Caloplaca \\
& holocarpa (Ach.) Wade, Candelariella reflexa (Nyl.) Lettau, \\
& Diploicia canescens (Dickson) Massal., Hyperphyscia adglutinata \\
nitrophytic & (Flörke) Mayrh. \& Poelt, Physcia adscendens (Fr.) Oliv., Physcia \\
& tenella (Scop.) DC. v. tenella, Physconia enteroxantha (Nyl.) Poelt, \\
& Physconia grisea (Lam.) Poelt, Ramalina canariensis J.Steiner, Xan- \\
& thoria parietina (L.) Th.Fr.. \\
\hline & Caloplaca ferruginea (Huds.) Th.Fr. 1861, Chrysothrix candelaris \\
& (L.) Laundon*, Evernia prunastri (L.) Ach., Lecanora albella (Pers.) \\
& Ach.*, Flavoparmelia caperata (L.) Hale, Flavoparmelia soredians \\
& (Nyl.) Hale, Parmelia sulcata Taylor, Parmelina tiliacea (Hoffm.) \\
& Hale, Pertusaria amara (Ach.) Nyl., Ramalina fastigiata (Pers.) Ach., \\
& Teloschistes chrysophthalmus (L.) Th.Fr.. \\
\hline & Parmotrema hypoleucinum (J.Steiner) Hale, Parmotrema reticulatum \\
(Taylor) M.Choisy, Ramalina farinacea (L.) Ach., Ramalina pusilla \\
Duby, Usnea ceratina Ach., Usnea rubicunda Stirton.
\end{tabular}

Species with * had their classification corrected after Pinho et al. (2011). None of the species found is known to fix nitrogen.

sampled in the same sites (Fig. 1). The LDVs were interpolated using ordinary kriging after analysis of the variograms (Pinho et al., 2011). Thus, the linear regressions used for calculating CLEs were based on the estimated LDVs and the observed $\left[\mathrm{NH}_{3}\right]_{\mathrm{atm}}(\mathrm{N}=18$, points located outside the lichen sampling sites spatial envelope were not used, Fig. 1). The decision to interpolate the LDVs and analyse the correlation with the measured $\left[\mathrm{NH}_{3}\right]_{\mathrm{atm}}$, rather than the other way round, was in order not to over-inflate the degrees of freedom associated with the correlation and because the LDV interpolations had a higher level of confidence due to the much larger number of samples. Both LDVs (LDVnitro and LDVoligo) yielded a robust geostatistical model (Pinho et al., 2011) and thus a reliable set of interpolated values. All mapping outputs, geostatistics analysis and spatial operations were done with ArcMap v.9.3 (ESRI), correlations and function fitting were performed with Statistica v.10.0 (Statsoft).

\section{Results and discussion}

\subsection{Patterns of nitrogen deposition and atmospheric ammonia}

Both $\mathrm{N}_{\text {dep }}$ and $\left[\mathrm{NH}_{3}\right]_{\text {atm }}$ displayed similar spatial patterns, decreasing exponentially with distance from the cow-barn (Fig. 2), which is in accordance to what has been observed in other studies with $\mathrm{N}_{\text {red }}$ point sources (Fowler et al., 1998; Sutton et al., 1998; Verhagen and van Diggelen, 2006). The extent of impact of the studied $\mathrm{N}_{\text {red }}$ source was found to be ca. $50 \mathrm{~m}$ for CLOs and ca. $90 \mathrm{~m}$ for CLEs, which corresponds to the distance above which we could find $\mathrm{N}_{\mathrm{dep}}$ and $\left[\mathrm{NH}_{3}\right]_{\mathrm{atm}}$ values lower than the critical limits established, respectively (see Sect. 3.2). The results confirm the short-range dispersion of $\mathrm{N}_{\text {red }}$ emitted from a point source found in other works (Sutton et al., 1998), but it may not be the same in other situations since it is dependent on the surrounding land-cover (e.g. trees vs. grass proportion) and on the number of animals in the barn (Adrizal et al., 2008; Verhagen and van Diggelen, 2006).

The $\mathrm{N}_{\text {dep }}$ values found in our work in the lichen sampling points ranged from $17.9 \mathrm{~kg} \mathrm{ha}^{-1} \mathrm{yr}^{-1}$ to $381.7 \mathrm{~kg} \mathrm{ha}^{-1} \mathrm{yr}^{-1}$. The values found in other studies near agricultural $\mathrm{N}_{\text {red }}$ sources presented lower maxima values, 5-104 (Hao et al., 2009), 11-80 (Pitcairn et al., 1998), 5-42 $\mathrm{kg} \mathrm{ha}^{-1} \mathrm{yr}^{-1}$ (Fowler et al., 1998). The higher maximum values found here could reflect the fact that we have estimated deposition at a very short distance from the barn, where the predicted $\mathrm{N}_{\text {dep }}$ is maximum, and this distance may vary between studies. It is important to note that the lowest $\mathrm{N}_{\text {dep }}$ value estimated, $17.9 \mathrm{~kg} \mathrm{ha}^{-1} \mathrm{yr}^{-1}$, was higher than the background value for the region, ca. $10 \mathrm{~kg} \mathrm{ha}^{-1} \mathrm{yr}^{-1}$. This suggests that all points in our study site were influenced by $\mathrm{N}$ emitted from the barn and did not reach the regional background $\mathrm{N}_{\text {dep }}$ value. This observation reinforces the importance of considering the LDVs from a control area in order to obtain values for lichens near the regional $\mathrm{N}_{\mathrm{dep}}$ background. The $\left[\mathrm{NH}_{3}\right]_{\mathrm{atm}}$ 

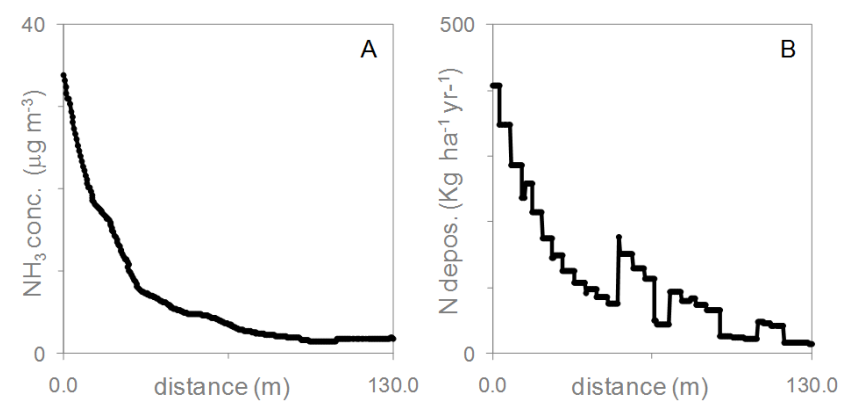

Fig. 2. Atmospheric ammonia concentration (A) and $\mathrm{N}$ deposition (B) along a transect from the $\mathrm{N}$ source (the cow barn, at distance 0 ) and up to $130 \mathrm{~m}$ distance, in the prevailing wind direction, SE. Atmospheric ammonia concentrations were calculated from a geostatistical model of measured ammonia concentrations for one year period, $\mathrm{N}$ deposition was calculated from LADD model. The elevated steps in the $\mathrm{N}$ deposition data are due to the differences between the deposition rates to trees and grassland.

found in our work ranged from $1.4 \mu \mathrm{g} \mathrm{m}^{-3}$ to $34.0 \mu \mathrm{g} \mathrm{m}^{-3}$, which are within the range of other studies around intensive agricultural areas: 2-60 $\mu \mathrm{g} \mathrm{m}^{-3}$ (Paoli et al., 2010), 7.3$98.2 \mu \mathrm{g} \mathrm{m}^{-3}$ (Rogers et al., 2009); 0.7-266.7 $\mu \mathrm{g} \mathrm{m}^{-3}$ (Frati et al., 2007); 0.3-106.2 $\mu \mathrm{g} \mathrm{m}^{-3}$ (McCulloch et al., 1998); 1.6$59 \mu \mathrm{g} \mathrm{m}^{-3}$ (Pitcairn et al., 1998); 0.5-60 $\mu \mathrm{g} \mathrm{m}^{-3}$ (Fowler et al., 1998).

\subsection{Critical load of nitrogen deposition and critical level of atmospheric ammonia}

We confirmed the initial hypothesis, that we could use the response of lichen functional groups at increasing distances from an agriculture $\mathrm{N}_{\text {red }}$ source to calculate CLOs and CLEs for semi-natural Mediterranean evergreen woodlands, using the modelled $\mathrm{N}_{\text {dep }}$ and the measured $\left[\mathrm{NH}_{3}\right]_{\mathrm{atm}}$. Based on the changes of LDVoligo, which were shown to be the most sensitive, the CLO for semi-natural Mediterranean evergreen woodlands can be considered $26 \mathrm{~kg} \mathrm{ha}^{-1} \mathrm{yr}^{-1}$ (Fig. 4). However, we found that the highest measured LDVoligo in the study site is lower than the regional control value, probably because all sampled points in the study site were still influenced by $\mathrm{N}$ from the barn, suggesting that the CLO should be lower than $26 \mathrm{~kg} \mathrm{ha}^{-1} \mathrm{yr}^{-1}$. This value is within the upper range suggested for other European forested seminatural ecosystems, using lichens as indicators, which vary between 10 to $25 \mathrm{~kg} \mathrm{ha}^{-1} \mathrm{yr}^{-1}$ (Bobbink et al., 2010). Based on the changes of LDVoligo the long-term CLE for seminatural Mediterranean evergreen woodlands was found to be lower than $1.9 \mu \mathrm{g} \mathrm{m}^{-3}$ because again, the highest measured LDVoligo was below the control value (Fig. 4). This CLE value is in agreement with recent studies pointing to the revision of CLEs of $\left[\mathrm{NH}_{3}\right]_{\mathrm{atm}}$ from $8 \mu \mathrm{g} \mathrm{m}^{-3}$ to $1 \mu \mathrm{g} \mathrm{m}^{-3}$ (Cape et al., 2009).

There is a general lack of studies regarding the effects of excessive $\mathrm{N}_{\text {dep }}$ and $\left[\mathrm{NH}_{3}\right]_{\text {atm }}$ on Mediterranean ecosys- tems excepting California (Bobbink et al., 2011; OchoaHueso et al., 2011), although California is quite diferent from Mediterranean-Europe on what regards historical and current land-use patterns and intensity. Furthermore, the few studies on the effects of increased $\mathrm{N}$ availability on the diversity of vascular plants within the European-Mediterranean ecosystems seem to be contradictory. An increase in total diversity was reported on maquis with a one year addition of 40 and $80 \mathrm{~kg} \mathrm{Nha}^{-1} \mathrm{yr}^{-1}$ (Dias et al., 2011) and in Spanish mountain heathlands located near Mediterranean climate areas with $\mathrm{N}_{\mathrm{dep}}$ of $56 \mathrm{~kg} \mathrm{ha}^{-1} \mathrm{yr}^{-1}$ (Calvo et al., 2005). Other studies reported no change in total species richness as the work performed in Italian grassland with $\mathrm{N}$ addition of $35 \mathrm{~kg} \mathrm{ha}^{-1} \mathrm{yr}^{-1}$ (Bonanomi et al., 2006). However, the effects of $\mathrm{N}_{\mathrm{dep}}$ and $\left[\mathrm{NH}_{3}\right]_{\mathrm{atm}}$ are much clearer when measures of functional groups instead of total diversity are used (Fenn et al., 2008), which is in accordance to what was observed in this work. The relation between LDVs and $\mathrm{N}_{\mathrm{dep}}$ and LDVs and $\left[\mathrm{NH}_{3}\right]_{\text {atm }}$ was highly significant $(P<0.0001)$, both $\mathrm{N}_{\text {dep }}$ and $\left[\mathrm{NH}_{3}\right]_{\text {atm }}$ presenting the same type of relationship to lichen functional groups: higher $\mathrm{N}_{\text {dep }}$ and $\left[\mathrm{NH}_{3}\right]_{\mathrm{atm}}$ led to a decrease of oligotrophic species (LDVoligo) and to an increase of nitrophytic ones (LDVnitro) (Figs. 3, 4). This has been observed in several studies in temperate (Fenn et al., 2007; Rogers et al., 2009; Wolseley et al., 2006) and Mediterranean ecosystems (Frati et al., 2007). However, unlike these previous works done in Mediterranean ecosystems, we monitored $\left[\mathrm{NH}_{3}\right]_{\mathrm{atm}}$ for a full year, allowing us to fully account for Mediterranean climate seasonality and variability in $\left[\mathrm{NH}_{3}\right]_{\mathrm{atm}}$. Moreover, other environmental factors that could influence lichens, such as industrial pollutants or regional climate (Giordani and Incerti, 2008; Pinho et al., 2008a), dust (Loppi and Pirintsos, 2000; Pinho et al., 2008b) or land-use intensity (Pinho et al., 2008; Stofer et al., 2006) were constant throughout our study site. Thus we were able to provide more accurate estimates of CLEs and CLOs for semi-natural areas for the first time for European Mediterranean ecosystems. Extrapolation from a single study area to all Mediterranean evergreen woodlands was based not only in the common type of semi-natural ecosystem (dominated by Quercus spp.) as well on the climate, which is similar across European-Mediterranean areas (when compared to other climates, e.g. temperate).

The CLOs found in this work are comparable to the ones, found in other semi-natural ecosystems (not Mediterranean), also calculated based on lichen diversity changes (Bobbink et al., 2010). However, the CLOs found for natural or unmanaged ecosystems, also based in lichen diversity changes, such as California forest (Fenn et al., 2008) and European tundra and mountain summits (Bobbink et al., 2011) are much lower (3-10 $\mathrm{kg} \mathrm{ha}^{-1} \mathrm{yr}^{-1}$ ) than the values found in this work. This difference can be due to the higher availability of $\mathrm{N}$ in semi-natural ecosystems than in natural ones. As a consequence in semi-natural ecosystems the more sensitive species, e.g. cyanolichens (Aragon et al., 2010), could 

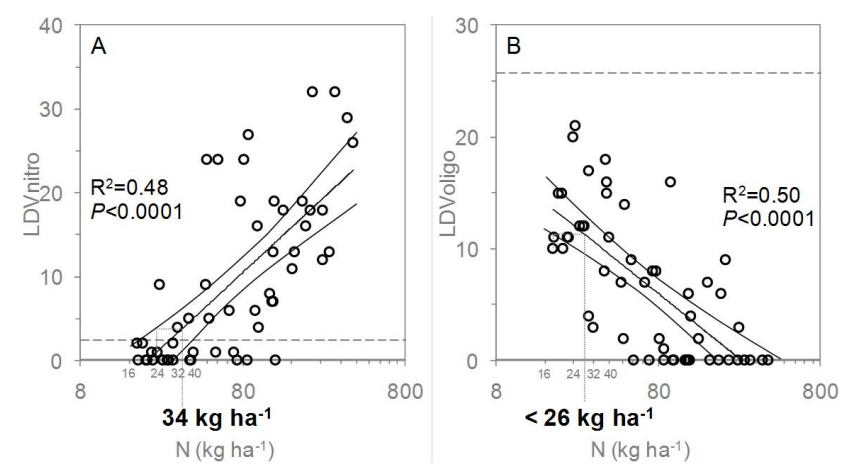

Fig. 3. Critical loads of $\mathrm{N}$ deposition considering the nitrophytic (A) and oligotrophic (B) functional groups. $\mathrm{N}$ deposition was calculated from LADD model and correlated to changes of LDVnitro (nitrophytic) and LDVoligo (oligotrophic). Considering the confidence intervals of the regression line (95\%) and the last point with a LDV still within the control values (dotted lines) the critical load was established. Because the observed values of LDVoligo are below the control value, a critical load lower than $26 \mathrm{~kg} \mathrm{ha}^{-1} \mathrm{yr}^{-1}$ should be considered.

already have been eliminated and thus the remaining community is more tolerant to small increases in N. Nevertheless it is critical to determine the thresholds for semi-natural ecosystems. In fact, conservative estimate suggest than only less than one quarter of Earth's ice-free land can be seen as wild (Ellis and Ramankutty, 2008), pressing humans to push towards sustainability of these so called anthromes (anthropogenic biomes) (Ellis, 2011). Mediterranean evergreen woodlands are among those semi-natural ecosystems with high biodiversity and that simultaneously provide a large number of other services to man, which depend on lowintensity human management (Bugalho et al., 2011). Finding critical thresholds for these systems is, therefore, crucial in order to set limits for management intensification and avoid losing current biodiversity.

It is interesting to note that the CLOs available in literature (Bobbink et al., 2011) appear to be dependent on the management intensity, but independent of climate, with similar CLOs found for different climates under the same management intensity. The CLEs available, although not including most ecosystems, (Cape et al., 2009) indicate that they are independent of both climate and management intensity. This independence of climate indicates that $\mathrm{N}$ may have the same type of impact on lichens communities worldwide, suggesting that lichens could be used as universal indicators for the impact of excessive $\mathrm{N}$.

By measuring $\left[\mathrm{NH}_{3}\right]_{\text {atm }}$ directly, we greatly reduced the uncertainty of the CLEs. However, for CLOs we could not measure all components of $\mathrm{N}_{\text {dep }}$. The best estimates of $\mathrm{N}_{\text {dep }}$ was therefore derived as the sum of (1) modelled $\mathrm{N}$ deposition from the LADD model for the study site, and (2) background $\mathrm{N}_{\text {dep }}$, estimated using the EMEP Unified Model (Simpson et al., 2003). This background estimate increased
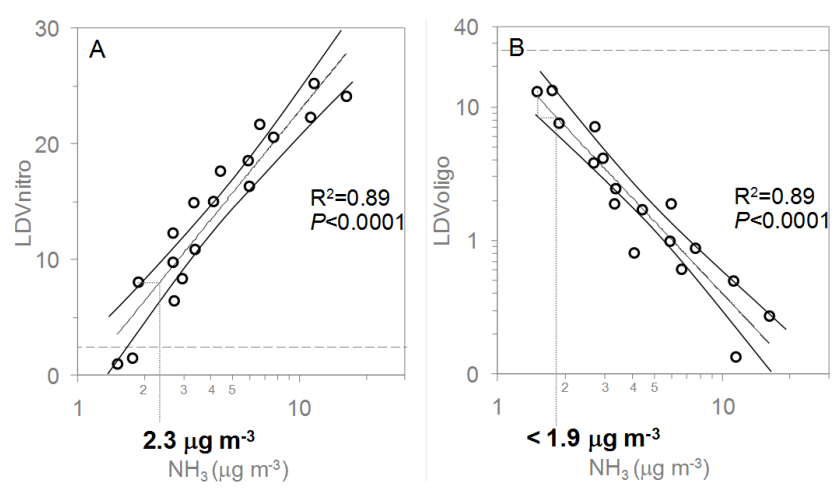

Fig. 4. Critical levels of atmospheric ammonia considering the nitrophytic (A) and oligotrophic (B) functional groups. The $\left[\mathrm{NH}_{3}\right]_{\mathrm{atm}}$ were measured for one year and correlated to changes of LDVnitro (nitrophytic) and LDVoligo (oligotrophic). Considering the confidence intervals of the regression line $(95 \%)$ and the first point with a LDV different from the control values (dotted lines) the critical level was established. Because the observed values of LDVoligo are below the control value, a critical level lower than $1.9 \mu \mathrm{g} \mathrm{m}^{-3}$ should be considered.

the uncertainty of the CLOs, because the real background $\mathrm{N}_{\mathrm{dep}}$ could be lower, due to the poor resolution of the EMEP model for Portugal $(50 \mathrm{~km})$. The study site is located in a grid cell which contains large industrial and urban areas, but is in fact located $10 \mathrm{~km}$ from the nearest small town (Alcochete), and $20 \mathrm{~km}$ from the larger cities (Lisboa, Setúbal and Montijo) and from the nearest industrial area (Barreiro). Therefore, the background $\mathrm{N}_{\text {dep }}$ due to $\mathrm{NO}_{\mathrm{x}}\left(5.1 \mathrm{~kg} \mathrm{ha}^{-1} \mathrm{yr}^{-1}\right)$ will be most probably overestimated for the study site, which in turn leads to an overestimation of CLOs. Thus it is of critical importance to produce maps of $\mathrm{N}_{\mathrm{dep}}$ in the future with a higher spatial resolution. Another aspect that may have originated an overestimation of the CLOs was the use of fixed deposition velocities for the LADD model. It has been suggested that $\mathrm{N}$ deposition velocity is dependent on $\left[\mathrm{NH}_{3}\right]_{\mathrm{atm}}$ (Flechard and Fowler, 1998), and thus the $\mathrm{N}_{\mathrm{dep}}$ could be smaller than the ones we calculated.

\subsection{Sensitivity of nitrophytic and oligotrophic lichens}

Although both LDVoligo and LDVnitro presented equally significant correlations to either $\mathrm{N}_{\text {dep }}$ or $\left[\mathrm{NH}_{3}\right]_{\mathrm{atm}}$, which was expected (Ruisi et al., 2005; Sparrius, 2007; Vilsholm et al., 2009), the CLOs and CLEs were always lower when considering LDVoligo (Figs. 3, 4). The highest observed LDVoligo observed in our study site was below the regional control value, whereas for LDVnitro a large number of sampling points were still within the range of the regional control value (Figs. 3, 4). This suggests that the oligotrophic functional group is more sensitive to increasing $\mathrm{N}$ availability than the nitrophytic one and/or that the nitrophytic functional group may require higher $\left[\mathrm{NH}_{3}\right]_{\mathrm{atm}}$ or $\mathrm{N}_{\text {dep }}$ driven by $\mathrm{N}_{\text {red }}$ to respond (Pinho et al., 2011). The differences between 
the response of nitrophytic and oligotrophic species to $\mathrm{N}_{\mathrm{dep}}$ or $\left[\mathrm{NH}_{3}\right]_{\mathrm{atm}}$ could be related to the capacity of nitrophytic species to prevent the accumulation of $\mathrm{N}$ in the cells, (GaioOliveira et al., 2005) which can be due to the capacity to provide sufficient carbon for $\mathrm{N}$ metabolism (Hauck, 2010). However, the mechanism by which excessive $\mathrm{N}$ influences lichens is currently under debate. An indirect effect of atmospheric ammonia on tree bark pH (van Herk, 2001) has been suggested; an effect that can be confounded/or correlated with the influence of dust, especially relevant in Mediterranean areas (Branquinho et al., 2008; Loppi and Pirintsos, 2000). Nevertheless it remains inconclusive if the change in bark $\mathrm{pH}$ is merely a consequence of pollution to which lichens are directly responding (Spier et al., 2010). Another possible mechanism includes direct toxicity of excessive $\mathrm{N}$ on oligotrophic species, for example on the performance of photosystem II (Paoli et al., 2010). However, independently of the actual mechanism, the different sensitivity to $\mathrm{N}$ of the oligotrophic and nitrophytic functional groups points to the preferential use of LDVoligo as the most sensitive tool to monitor the effects of low $\mathrm{N}_{\text {dep }}$ (driven by $\mathrm{N}_{\text {red }}$ ) and $\left[\mathrm{NH}_{3}\right]_{\mathrm{atm}}$. This is critical in establishing thresholds in highly disturbed areas, where only the most tolerant species remain (Frati et al., 2007): in these areas if a control value is not taken into account the CLOs and CLEs calculated can be largely overestimated.

\section{Conclusions}

The more important outcome of this work was that, by modelling the highly significant relationship between LDVs and $\mathrm{N}_{\text {dep }}$ and LDVs and $\left[\mathrm{NH}_{3}\right]_{\text {atm }}$ we could establish critical thresholds for $\mathrm{N}$, for the first time for European Mediterranean evergreen woodlands, a semi-natural ecosystem. The critical loads for $\mathrm{N}$ deposition were considered to be below $26 \mathrm{~kg} \mathrm{ha}^{-1} \mathrm{yr}^{-1}$ and the long-term critical levels of atmospheric ammonia were found to be below $1.9 \mu \mathrm{g} \mathrm{m}^{-3}$. The critical levels found were similar to the concentrations established for other ecosystems. The critical loads found were within the upper range of the critical loads for other seminatural ecosystems, but higher than for natural ones.

Acknowledgements. We thank funding from FCTMCTES (BD/17880/2004, BPD/75425/2010 and research projects PTDC/AAC-CLI/104913/2008 and PTDC/BIABEC/099323/2008) and from COST729. We also thank Professor António Mineiro for allowing the use of his farm and assistance during the fieldwork and Força Aérea Portuguesa (BA6) for providing the meteorological data.

Edited by: S. Reis and J. Sprent

\section{References}

Adrizal, A., Patterson, P. H., Hulet, R. M., Bates, R. M., Myers, C. A. B., Martin, G., Shockey, R. L., Van der Grinten, M., Anderson, D. A., and Thompson, J. R.: Vegetative Buffers for Fan Emissions from Poultry Farms: 2. Ammonia, Dust and Foliar Nitrogen, J. Environ. Sci. Health Part B-Pestic. Contam. Agric. Wastes, 43, 96-103, 2008.

Aragon, G., Martinez, I., Izquierdo, P., Belinchon, R., and Escudero, A.: Effects of Forest Management on Epiphytic Lichen Diversity in Mediterranean Forests, Appl. Veg. Sci., 13, 183-194, 2010.

Asta, J., Erhardt, W., Ferretti, M., Fornasier, F., Kirschbaum, U., Nimis, P.L., Purvis, O. W., Pirintsos, S., Scheidegger, C., van Haluwyn, C., and Wirth, V.: Mapping Lichen Diversity as an Indicator of Environmental Quality, in: Monitoring with LichensMonitoring Lichens, edited by: Nimis, P. L., Scheidegger, C., and Wolseley P. A., Kluwer Academic Publisher, 2002.

Augusto, S., Maguas, C., Matos, J., Pereira, M. J., Soares, A., and Branquinho, C.: Spatial Modeling of Pahs in Lichens for Fingerprinting of Multisource Atmospheric Pollution, Environ. Sci. Technol., 43, 7762-7769, 2009.

Blondel, J. and Aronson, J.: Biology and Wildlife of the Mediterranean Region, Oxford University Press, New York, 1999.

Bobbink, R., Hicks, K., Galloway, J., Spranger, T., Alkemade, R., Ashmore, M., Bustamante, M., Cinderby, S., Davidson, E., Dentener, F., Emmett, B., Erisman, J:W., Fenn, M., Gilliam, F., Nordin, A., Pardo, L., and De Vries, W.: Global Assessment of Nitrogen Deposition Effects on Terrestrial Plant Diversity: A Synthesis, Ecol. Appl., 20, 30-59, 2010.

Bobbink, R., Braun, S., Nordin, A., Power, S., Schütz, K., Strengbom, J., Weijters, M., and Tomassen, M.: Review and Revision of Empirical Critical Loads and Dose-Response Relationships, Coordination Centre for Effects, National Institute for Public Health and the Environment (RIVM), The Netherlands, 2011.

Bonanomi, G., Caporaso, S., and Allegrezza, M.: Short-Term Effects of Nitrogen Enrichment, Litter Removal and Cutting on a Mediterranean Grassland, Acta Oecol.-Int. J. Ecol., 30, 419-425, 2006.

Branquinho, C., Gaio-Oliveira, G., Augusto, S., Pinho, P., Maguas, C., and Correia, O.: Biomonitoring Spatial and Temporal Impact of Atmospheric Dust from a Cement Industry, Environ. Pollut., 151, 292-299, 2008.

Bugalho, M. N., Caldeira, M. C., Pereira, J. S., Aronson, J., and Pausas, J. G.: Mediterranean cork oak savannas require human use to sustain biodiversity and ecosystem services, Front. Ecol. Environ., 9, 278-286, 2011.

Calvo, L., Alonso, I., Fernandez, A. J., and De Luis, E.: ShortTerm Study of Effects of Fertilisation and Cutting Treatments on the Vegetation Dynamics of Mountain Heathlands in Spain, Plant Ecol., 179, 181-191, 2005.

Cape, J. N., van der Eerden, L. J., Sheppard, L. J., Leith, I. D., and Sutton, M. A.: Evidence for Changing the Critical Level for Ammonia, Environ. Pollut., 157, 1033-1037, 2009.

Cruz, C. and Martins-Loução, M. A.: Determination of Ammonium Concentrations in Soils and Plant Extracts, in: Nitrogen in a Sustainable Ecosystem: From the Cell to the Plant, edited by: Martins-Loução M. A. and Lips, S.H., Backhuys Publishers, 2000. 
Davies, E. D., Moss, D., and Hill, M. O.: Eunis Habitat Classification Revised, European Environment Agency, European topic centre on nature protection and biodiversity, 2004.

Dias, T., Malveiro, S., Martins-Loucao, M. A., Sheppard, L. J., and Cruz, C.: Linking N-Driven Biodiversity Changes with Soil N Availability in a Mediterranean Ecosystem, Plant Soil, 341, 125136, 2011.

Dragosits, U., Theobald, M. R., Place, C. J., Lord, E., Webb, J., Hill, J., ApSimon, H. M., and Sutton, M. A.: Ammonia Emission, Deposition and Impact Assessment at the Field Scale: A Case Study of Sub-Grid Spatial Variability, Environ. Pollut., 117, 147158, 2002.

EEA, European Environment Agency: Emep/Corinair Emission Inventory Guidebook, 2007.

Erisman, J. W., Sutton, M. A., Galloway, J., Klimont, Z., and Winiwarter, W.: How a Century of Ammonia Synthesis Changed the World, Nat. Geosci., 1, 636-639, 2008.

Ellis, E. C.: Anthropogenic transformation of the terrestrial biosphere, Philos. Trans. R. Soc. A-Math. Phys. Eng. Sci. , 369, 1010-1035, 2011.

Ellis, E. C. and Ramankutty, N.: Putting people in the map: anthropogenic biomes of the world, Front. Ecol. Environ., 6, 439-447, 2008.

Farina, A., Santolini, R., Pagliaro, G., Scozzafava, S., and Schipani, I.: Eco-semiotics: A new field of competence for ecology to overcome the frontier between environmental complexity and human culture in the Mediterranean, Isr. J. Plant Sci., 53, 167175, 2005.

Feest, A. and Spanos, K.: An approach to measuring biodiversity and its use in analysing the effect of nitrogen deposition on woodland butterfly populations in the Netherlands, IForestbiogeosciences and forestry, 2, 46-48, 2009.

Fenn, M. E., Geiser, L., Bachman, R., Blubaugh, T. J., and Bytnerowicz, A.: Atmospheric Deposition Inputs and Effects on Lichen Chemistry and Indicator Species in the Columbia River Gorge, Usa, Environ. Pollut., 146, 77-91, 2007.

Fenn, M. E., Jovan, S., Yuan, F., Geiser, L., Meixner, T., and Gimeno, B. S.: Empirical and Simulated Critical Loads for Nitrogen Deposition in California Mixed Conifer Forests, Environ. Pollut., 155, 492-511, 2008.

Fenn, M. E., Allen, E. B., Weiss, S. B., Jovan, S., Geiser, L. H., Tonnesen, G. S., Johnson, R. F., Rao, L. E., Gimeno, B. S., Yuan, F., Meixner, T., and Bytnerowicz, A.: Nitrogen Critical Loads and Management Alternatives for N-Impacted Ecosystems in California, J. Environ. Manage., 91, 2404-2423, 2010.

Flechard, C. R. and Fowler, D.: Atmospheric ammonia at a moorland site. II: Long-term surface-atmosphere micrometeorological flux measurements. Q. J. Roy. Meteorol. Soc., 124, 759-791, 1998.

Fowler, D., Pitcairn, C. E. R., Sutton, M. A., Flechard, C., Loubet, B., Coyle, M., and Munro, R. C.: The Mass Budget of Atmospheric Ammonia in Woodland within $1 \mathrm{Km}$ of Livestock Buildings, Environ. Pollut., 102, 343-348, 1998.

Frati, L., Santoni, S., Nicolardi, V., Gaggi, C., Brunialti, G., Guttova, A., Gaudino, S., Pati, A., Pirintsos, S. A., and Loppi, S.: Lichen Biomonitoring of Ammonia Emission and Nitrogen Deposition around a Pig Stockfarm, Environ. Pollut., 146, 311-316, 2007.
Gaio-Oliveira, G., Dahlman, L., Palmqvist, K., Martins-Loucao, M., and Maguas, C.: Nitrogen Uptake in Relation to Excess Supply and Its Effects on the Lichens Evernia Prunastri (L.) Ach and Xanthoria Parietina (L.) Th. Fr, Planta, 220, 794-803, 2005.

Galloway, J. N., Aber, J. D., Erisman, J. W., Seitzinger, S. P., Howarth, R. W., Cowling, E. B., and Cosby, B. J.: The Nitrogen Cascade, Bioscience, 53, 341-356, 2003.

Geiser, L., Jovan, S., Glavich, D., and Porter, M.: Lichen based critical loads for atmospheric nitrogen deposition in Western Oregon and Washington Forests,USA. Environ. Pollut., 158, 2412-2421, 2010.

Giordani, P.: Is the Diversity of Epiphytic Lichens a Reliable Indicator of Air Pollution? A Case Study from Italy, Environ. Pollut., 146, 317-323, 2007.

Giordani, P. and Incerti, G.: The Influence of Climate on the Distribution of Lichens: A Case Study in a Borderline Area (Liguria, Nw Italy), Plant Ecol., 195, 257-272, 2008.

Hallsworth, S., Dore, A. J., Bealey, W. I., Dragosits, U., Vieno, M., Hellsten, S., Tang, Y. S., and Sutton, M. A.: The Role of Indicator Choice in Quantifying the Threat of Atmospheric Ammonia to the "Natura 2000" Network, Environ. Sci. Policy, 13, 671-687, 2010.

Hao, X. Y., Benke, M. B., Chang, C., Janzen, H. H., Clayton, G. W., and Hill, B. R.: Spatial Pattern of Ammonia Sorption by Soil and Vegetation Downwind of a Beef Feedlot, Agric. Ecosyst. Environ., 132, 39-47, 2009.

Hauck, M.: Ammonium and Nitrate Tolerance in Lichens, Environ. Pollut., 158, 1127-1133, 2010.

Lavorel, S. and Garnier, E.: Predicting Changes in Community Composition and Ecosystem Functioning from Plant Traits: Revisiting the Holy Grail, Funct. Ecol., 16, 545-556, 2002.

Loppi, S. and Pirintsos, S. A.: Effect of Dust on Epiphytic Lichen Vegetation in the Mediterranean Area (Italy and Greece), Isr. J. Plant Sci., 48, 91-95, 2000.

Manning, P., Newington, J. E., Robson, H. R., Saunders, M., Eggers, T., Bradford, M. A., Bardgett, R. D., Bonkowski, M., Ellis, R. J., Gange, A. C., Grayston, S. J., Kandeler, E., Marhan, S., Reid, E., Tscherko, D., Godfray, H. C. J., and Rees, M.: Decoupling the Direct and Indirect Effects of Nitrogen Deposition on Ecosystem Function, Ecol. Lett., 9, 1015-1024, 2006.

McCulloch, R. B., Few, G. S., Murray, G. C., and Aneja, V. P.: Analysis of Ammonia, Ammonium Aerosols and Acid Gases in the Atmosphere at a Commercial Hog Farm in Eastern North Carolina, Usa, Environ. Pollut., 102, 263-268, 1998.

Mittermeier, R. A., Gil, P. R., Hoffman, M., Pilgrim, J., Brooks, T., Cristina Goettsch Mittermeier, Lamoreux, J., and da Fonseca, G. A. B.: Hotspots Revisited - Earth's Biologically Richest and Most Endangered Terrestrial Ecoregions, Conservation International and CEMEX, Mexico City, pp. 392, 2005.

Myers, N., Mittermeier, R. A., Mittermeier, C. G., da Fonseca, G. A. B., and Kent, J.: Biodiversity hotspots for conservation priorities, Nature, 403, 853-858, 2000.

Nilsson, J. and Grennfelt, P.: Critical Loads for Sulphur and Nitrogen, in: Report from a Workshop Held at Skokloster, edited by: Nilsson, J. and Grennfelt, P., Sweden, Nordic Council of Ministers, 1988.

Nimis, P. L., and Martellos, S.: Italic - the Information System on Italian Lichens V. 4.0, University of Trieste, Dept. of Biology, IN4.0/1, available at: http://dbiodbs.univ.trieste.it, 2008. 
Ochoa-Hueso, R., Allen, E. B., Branquinho, C., Cruz, C., Dias, T., Fenn, M. A., Manrique, E., Pérez-Corona, E., Sheppard, L. J., and Stock, W. D.: Nitrogen Deposition Effects on Mediterranean-Type Ecosystems: An Ecological Assessment, Environ. Pollut., 159, 14, doi:10.1016/j.envpol.2010.12.019, 2011.

Paoli, L., Pirintsos, S. A., Kotzabasis, K., Pisani, T., Navakoudis, E., and Loppi, S.: Effects of Ammonia from Livestock Farming on Lichen Photosynthesis, Environ. Pollut., 158, 2258-2265, 2010.

Paracchini, M. L., Petersen, J. E., Hoogeveen, Y., Bamps, C., Burfield, I., and van-Swaay, C.: 2008. High Nature Value Farmland in Europe - An Estimate of the Distribution Patterns on the Basis of Land Cover and Biodiversity Data, EUR - Scientific and Technical Research series, Joint Research Centre - Institute for Environment and Sustainability, Luxembourg, pp. 87, 2008.

Pardo, L. H., Robin-Abbott, M. J., and Driscoll, C. T. (Eds).: Assessment of Nitrogen deposition effects and empirical critical loads of Nitrogen for ecoregions of the United States, Report NRS-80, US Department of Agriculture, Forest Service, Northern Research Station, 2011.

Pinho, P., Augusto, S., Branquinho, C., Bio, A., Pereira, M. J., Soares, A., and Catarino, F.: Mapping Lichen Diversity as a First Step for Air Quality Assessment, J. Atmos. Chem., 49, 377-389, 2004.

Pinho, P., Augusto, S., Maguas, C., Pereira, M. J., Soares, A., and Branquinho, C.: Impact of Neighbourhood Land-Cover in Epiphytic Lichen Diversity: Analysis of Multiple Factors Working at Different Spatial Scales, Environ. Pollut., 151, 414-422, 2008a.

Pinho, P., Augusto, S., Martins-Loucao, M. A., Pereira, M. J., Soares, A., Maguas, C., and Branquinho, C.: Causes of Change in Nitrophytic and Oligotrophic Lichen Species in a Mediterranean Climate: Impact of Land Cover and Atmospheric Pollutants, Environ. Pollut., 154, 380-389, 2008b.

Pinho, P., Branquinho, C., Cruz, C., Tang, Y. S., Dias, T., Rosa, A. P., Maguas, C., Martins-Loucao, M. A., and Sutton, M. A.: Assessment of Critical Levels of Atmospheric Ammonia for Lichen Diversity in Cork-Oak Woodland, Portugal, in: Atmospheric Ammonia, edited by: Sutton, M. A., Reis, S., and Baker, S. M. H., Springer, 2009.

Pinho, P., Dias, T., Cruz, C., Tang, Y. S., Sutton, M. A., MartinsLoucao, M. A., Maguas, C., and Branquinho, C.: Using Lichen Functional Diversity to Assess the Effects of Atmospheric Ammonia in Mediterranean Woodlands, J. Appl. Ecol., 48, 11071116, 2011.

Pinho, P., Bergamini, A., Carvalho, P., Branquinho, C., Stofer, S., Scheidegger, C, and Maguas, C.: Lichen Functional Groups as Ecological Indicators of the Effects of Land-Use in Mediterranean Ecosystems, Ecol. Indic., 15, 36-42, 2012.

Pitcairn, C. E. R., Leith, I. D., Sheppard, L. J., Sutton, M. A., Fowler, D., Munro, R. C., Tang, S., and Wilson, D.: The Relationship between Nitrogen Deposition, Species Composition and Foliar Nitrogen Concentrations in Woodland Flora in the Vicinity of Livestock Farms, Environ. Pollut., 102, 41-48, 1998.

Plieninger, T., Hochtl, F., and Spek, T.: Traditional land-use and nature conservation in European rural landscapes, Environ. Sci. Policy, 9, 317-321, 2006.

Reis, S., Pinder, R. W., Zhang, M., Lijie, G., and Sutton, M. A.: Reactive nitrogen in atmospheric emission inventories, Atmos. Chem. Phys., 9, 7657-7677, doi:10.5194/acp-9-7657-2009,
2009.

Rockstrom, J., Steffen, W., Noone, K., Persson, A., Chapin, F. S., Lambin, E. F., Lenton, T. M., Scheffer, M., Folke, C., Schellnhuber, H. J., Nykvist, B., de Wit, C. A., Hughes, T., van der Leeuw, S., Rodhe, H., Sorlin, S., Snyder, P. K., Costanza, R., Svedin, U., Falkenmark, M., Karlberg, L., Corell, R. W., Fabry, V. J., Hansen, J., Walker, B., Liverman, D., Richardson, K., Crutzen, P., and Foley, J. A.: A Safe Operating Space for Humanity, Nature, 461, 472-475, 2009.

Roda, F., Avila, A., and Rodrigo, A.: Nitrogen Deposition in Mediterranean Forests, Environ. Pollut., 118, 205-213, 2002.

Rogers, P. C., Moore, K. D., and Ryel, R. J.: Aspen Succession and Nitrogen Loading: A Case for Epiphytic Lichens as Bioindicators in the Rocky Mountains, USA, J. Veg. Sci., 20, 498-510, 2009.

Ruisi, S., Zucconi, L., Fornasier, F., Paoli, L., Frati, L., and Loppi, S.: Mapping Environmental Effects of Agriculture with Epiphytic Lichens, Isr. J. Plant Sci., 53, 115-124, 2005.

Scheffer, M., Bascompte, J., Brock, W. A., Brovkin, V., Carpenter, S. R., Dakos, V., Held, H., van Nes, E. H., Rietkerk, M., and Sugihara, G.: Early-Warning Signals for Critical Transitions, Nature, 461, 53-59, 2009.

Simpson, D., Fagerli, H., Jonson, J.E., Tsyro, S., Wind, P., and Tuovinen, J.P.: The Emep Unified Eulerian Model: model Description, Emep Msc-W Report 1/2003; The Norwegian Meteorological Institute, 2003.

Sparrius, L. B.: Response of Epiphytic Lichen Communities to Decreasing Ammonia Air Concentrations in a Moderately Polluted Area of the Netherlands, Environ. Pollut., 146, 375-379, 2007.

Spier, L., van Dobben, H., and van Dort, K.: Is Bark Ph More Important Than Tree Species in Determining the Composition of Nitrophytic or Acidophytic Lichen Floras?, Environ. Pollut., 158, 3607-3611, 2010.

Stofer, S., Bergamini, A., Aragon, G., Carvalho, P., Coppins, B. J., Davey, S., Dietrich, M., Farkas, E., Karkkainen, K., Keller, C., Lokos, L., Lommi, S., Maguas, C., Mitchell, R., Pinho, P., Rico, V. J., Truscott, A. M., Wolseley, P. A., Watt, A., and Scheidegger, C.: Species Richness of Lichen Functional Groups in Relation to Land Use Intensity, Lichenologist, 38, 331-353, 2006.

Sutton, M. A., Milford, C., Dragosits, U., Place, C. J., Singles, R. J., Smith, R. I., Pitcairn, C. E. R., Fowler, D., Hill, J., ApSimon, H. M., Ross, C., Hill, R., Jarvis, S. C., Pain, B. F., Phillips, V. C., Harrison, R., Moss, D., Webb, J., Espenhahn, S. E., Lee, D. S., Hornung, M., Ullyett, J., Bull, K. R., Emmett, B. A., Lowe, J., and Wyers, G. P.: Dispersion, Deposition and Impacts of Atmospheric Ammonia: Quantifying Local Budgets and Spatial Variability, Environ. Pollut., 102, 349-361, 1998.

Sutton, M. A., Miners, B., Tang, Y. S., Milford, C., Wyers, G. P., Duyzer, J. H., and Fowler, D.: Comparison of Low Cost Measurement Techniques for Long-Term Monitoring of Atmospheric Ammonia, J. Environ. Monit., 3, 446-453, 2001.

Tang, Y. S., Cape, J. N., and Sutton, M.A.: Development and Types of Passive Samplers for Nh3 and $\mathrm{No}_{\mathrm{x}}$, TheScientificWorld, 1, 513-529, 2001.

Theobald, M. R., Dragosits, U., Place, C. J., Smith, J. U., Sozanska, M., Brown, L., Scholefield, D., Del prado, A., Webb, J., Whitehead, P. G., Angus, A., Hodge, I. D., Fowler, D., and Sutton, M. A.: Modelling Nitrogen Fluxes at the Landscape Scale, Water, Air and Soil Pollution: Focus, 4, 135-142, 2004. 
UNEP: United Nations Environment Programme and WHRC, Woods Hole Research Center: Reactive Nitrogen in the Environment: Too Much or Too Little of a Good Thing, United Nations, 2007.

van Herk, C. M.: Bark Ph and Susceptibility to Toxic Air Pollutants as Independent Causes of Changes in Epiphytic Lichen Composition in Space and Time, Lichenologist, 33, 419-441, 2001.

Verhagen, R. and van Diggelen, R.: Spatial Variation in Atmospheric Nitrogen Deposition on Low Canopy Vegetation, Environ. Pollut., 144, 826-832, 2006.
Vilsholm, R. L., Wolseley, P. A., Sochting, U., and Chimonides, P. J.: Biomonitoring with Lichens on Twigs, Lichenologist, 41, 189-202, 2009.

Wolseley, P. A., James, P. W., Theobald, M. R., and Sutton, M. A.: Detecting Changes in Epiphytic Lichen Communities at Sites Affected by Atmospheric Ammonia from Agricultural Sources, Lichenologist, 38, 161-176, 2006. 